\title{
Co MÓWI AUTYZM? SPOJRZENIE FILOZOFII JĘZYKA W OPARCIU O MYŚL Ludwiga Wittgensteina i Johna Searle'a
}

\author{
Karaś Mateusz, mkaras@amu.edu.pl \\ Uniwersytet im. Adama Mickiewicza w Poznaniu \\ Ul. Wieniawskiego 1, 61-712 Poznań
}

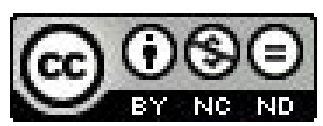

\begin{abstract}
Abstrakt
Celem tego artykułu jest odniesienie niektórych koncepcji z filozofii języka do kwestii autyzmu. Przykłady osób z różnymi niepełnosprawnościami pokazuja, że język nie jest tym samym dla każdego. Osoby z autyzmem są jednym z takich przykładów, który może nam ukazać różnice w postrzeganiu i używaniu języka przez jednostki, co może dać szerszą perspektywę w spojrzeniu na sam język. Artykuł ten jest głównie oparty na dwóch eksperymentach myślowych zaprezentowanych przez Ludwiga Wittgensteina: „żuk w pudełku” oraz Johna Searléa: „,hiński pokój”", których zestawienie pokaże, że możemy rozumieć zarówno autyzm, jak i język w odmienny niż dotychczas sposób.

Słowa kluczowe: autyzm, język, filozofia języka, Ludwig Wittgenstein, John Searle, chiński pokój, żuk w pudełku, komunikacja

What does autism say? Philosophy of language perspective based on ideas of Ludwig Wittgenstein and John Searle

\section{Abstract}

The aim of this paper is to refer some ideas of philosophy of language to autism. People with autism are one of such examples that can show us differences in perceiving and using language by individuals which can give us a broader perspective on language itself. This paper is mainly based on two mental experiments brought by Ludwig Wittgenstein - "beetle in the box" and John Searle - "Chinese room", to show that we can understand language and autism in different way.

Key words: autism, language, philosophy of language, Ludwig Wittgenstein, John Searle, beetle in the box, Chinese room, communication
\end{abstract}

\section{WPROWADZENIE}

Porozumiewanie się z innymi ludźmi jest dla każdego fundamentem istnienia w społeczeństwie. Bez tej umiejętności jednostka staje się odizolowana i niezdolna do życia wśród innych. Wiele przykładów związanych z szeroko pojętą niepełnosprawnością wskazuje na słuszność tego intuicyjnego stwierdzenia. Autyzm jest tu jednym z najbardziej wyrazistych przypadków, w którym uwidacznia się waga poprawnej komunikacji. Jednakże, co może dać takie spostrzeżenie w odniesieniu do filozofii języka? Ta ostatnia zajmuje się językiem i jego relacją z człowiekiem, światem, poznaniem, znaczeniem. Tworzy się przy tym teorie, które próbują wytłumaczyć to, jak funkcjonuje język i jaką spełnia rolę. Jednak teorie te nie uwzględniają przypadków takich jak autyzm, w których język zdaje się funkcjonować odmiennie niż jest to ogólnie przyjęte w naukach zajmujących się tą problematyką. Czy w takim razie autyzm jest nam w stanie powiedzieć coś o języku? A także, czy spojrzenie filozofii języka może być wykorzystane w pogłębieniu rozumienia tego zjawiska?

Wyobraźmy sobie dwójkę dzieci, które posiadają w swoich domach niezliczoną liczbę zabawek. Niestety nie mogą pokazywać ich sobie nawzajem. Rodzice każą im dbać o nie, trzymać w pudełkach i nie wynosić z domu. Każde pudełko musi mieć na sobie nazwę danej zabawki, która powinna się w nim znajdować, gdy dzieci się nimi nie bawią. Pewnego dnia, dzieci po kryjomu postanawiają wymienić się kilkoma pudełkami. Po powrocie do swoich domów otwierają je ze zniecierpliwieniem. Jaka jest jednak gwarancja, że w pudełku z napisem „samochód”, faktycznie znajduje się samochód? Być może jedno z dzieci przeżyje rozczarowanie, gdy odkryje, że w pudełku tym znajduje się samolot, albo co gorsza, nic w nim nie ma.

Powyższy eksperyment myślowy pomoże w zrozumieniu tez, które zostaną tu przedstawione. Można go odnieść do językowego funkcjonowania człowieka w świecie. Każdy z nas posiada doświadczenia zmysłowe oraz pewne wewnętrzne przeżycia z nimi związane. Ale co umożliwia nam porządkowanie tych doświadczeń w sposób, który pozwalałby na porozumiewanie się z innymi? Jest to język. „Zabawki” mogą tu być traktowane jako szeroko pojęte doświadczenie, 
zawierające zarówno percepcje zmysłowe, jak i przeżycia wewnętrzne. „Pudełka” zaś to język, w którym ujmujemy owo doświadczenie. Jednak posługując się samym tylko językiem mamy dostęp jedynie do „pudełek”, nie do zawartości.

Wszystko stanie się jasne, gdy cała ta kwestia zostanie przedstawiona w świetle filozofii. Wykorzystane zostaną tu trzy motywy: perspektywa kantowska w odniesieniu do języka ${ }^{1}$ oraz dwa eksperymenty myślowe: „żuk w pudełku”2 Ludwiga Wittgensteina oraz „"chiński pokójj”3 Johna Searle'a - autorów wspomnianych w tytule tego tekstu. Perspektywa kantowska wyjaśni, dlaczego możemy postrzegać ludzki język jako pojemnik na doświadczenie, „żuk w pudełku” wskaże, że nie da się dotrzeć do zawartości „pudełka” drugiej osoby, natomiast „, chiński pokój”" uwidoczni zaistnienie sytuacji, w której możliwe jest posługiwanie się „pudełkami” bez zawartości, lecz jednocześnie wskaże na konieczność istnienia w umyśle głębszych stanów psychicznych.

Jak to wszystko, co zostało powiedziane powyżej, odnosi się do problematyki autyzmu? Po pierwsze, dzięki przedstawionej tu perspektywie stanie się możliwym pokazanie zaburzeń komunikacji z nim związanych w nowy sposób, opartym na refleksji nad językiem. Po drugie, sama ta refleksja również zyska nowy punkt odniesienia, który nie był do tej pory brany pod uwagę. Będzie można zobaczyć, że język nie spełnia takiej samej roli dla każdejjednostki. Stanie się też możliwe wyciagnięcie wniosku, że język może być również takim samym przedmiotem doświadczenia jak np. jakości zmysłowe.

\section{JEZYK JAKO „POJEMNIK NA DOŚWIADCZENIE” - PERSPEKTYWA KANTOWSKA}

Whistorii filozofii dochodziło do wielu momentów, które można by nazwać przełomowymi. Zmieniały one perspektywę spojrzenia na rzeczywistość oraz nadawały nowy ton całej refleksji filozoficznej. Jednym z takich momentów przełomowych było niewątpliwie dzieło Immanuela Kanta pt. Krytyka czystego rozumu opublikowana w roku 1781 ${ }^{4}$, w którym autor sformułował tezy, które będą tu punktem wyjścia dla dalszych rozważań. Filozof przedstawił nowatorskie podejście, któremu nadał nawet miano przewrotu kopernikańskiego w filozofii ${ }^{5}$. Chodziło o zmianę perspektywy, ze skupiania się na przedmiotach poznania, na skupienie się na podmiocie poznającym.

I. Kant uznawał, że nasza wiedza pochodzi ze zmysłów, ale oprócz tego mamy także pewne wrodzone formy poznania, poprzez które możemy doświadczać rzeczywistość. Dlatego możemy mówić o poznaniu wewnętrznym (a priori) oraz zewnętrznym, pochodzacym ze zmystów (a posteriori) ${ }^{6}$. Niemiecki filozof wskazuje, że nie moglibyśmy poznawać otaczającej nas rzeczywistości bez wewnętrznych warunków, które by nam na to pozwalały. Nasz umysł wyposażony jest w swego rodzaju formy, które porządkują nasze doświadczenie. Tak więc to podmiot poznający staje się tutaj punktem wyjścia. Poznajemy rzeczywistość tylko poprzez już istniejące w nas formy, które porządkują doświadczenie. Odnosząc tę kwestię do dzisiejszej terminologii można powiedzieć, że zarówno nasze aparaty percepcyjne, jak i sposób w jaki funkcjonuje mózg, są filtrem, przez który przechodzą wrażenia zmysłowe. Nie poznajemy rzeczywistości taka, jaką ona jest, tylko taka, jak się nam ona jawi poprzez nasze zmysły. Nie możemy oderwać się od sposobu, w jaki nasze oczy, uszy itd. przetwarzają docierające do nich dane. Dlatego można powiedzieć, że nie poznajemy rzeczy „samych w sobie”.

Odnosi się to do wcześniejszej metafory „pudełek”. Można je bowiem przyrównać do form umysłu, o których wspominał I. Kant. Odpowiednie „pudełko” zawiera w sobie określone wrażenia, przychodzące do nas z rzeczywistości zewnętrznej.

Myśl autora przewrotu kopernikańskiego w filozofii była rozwijana jeszcze wiele lat po jego śmierci. Wielu filozofów odniosło jego sposób myślenia także do kwestii języka. Pierwszym takim interpretatorem I. Kanta stał się Wilhelm von Humboldt. Do myśli poprzednika o formach poznania dodał on właśnie język jako kolejną z form, dzięki której poznajemy rzeczywistość. To połączenie formy i danych zmysłowych pozwala nam na poznawanie rzeczywistości ${ }^{8}$. Według $\mathrm{W}$. von Humboldta bez języka nie byłoby nawet prawdziwego myślenia9. Można powiedzieć, że język staje się „pudełkiem”, w które wkładamy nasze doświadczenie.

Spojrzenie takie było rozwijane również przez kolejnych myślicieli. Najważniejszym z nich jest niewątpliwie Ernst

1 Zob. B. Andrzejewski, Poznanie i komunikacja, Koszalin 2010.

2 L. Wittgenstein, Dociekania filozoficzne, Warszawa 2000, s. 144

3 J. Searle, Umyst, mózg i nauka, Warszawa 1995, s. 28-30.

4 Zob. W. Tatarkiewicz, Historia filozofii, T. II, Warszawa 2007, s. 123.

5 Zob. Tamże, s. 129.

6 Zob. I. Kant, Krytyka czystego rozumu, T. I, Warszawa 1957, s. 60-61.

7 Zob. Tamże, s. 95 .

8 Zob. B. Andrzejewski, Poznanie..., dz. cyt., s. 38.

9 Zob. W. von Humboldt, Natura i wlaściwości języka, [w:] B. Andrzejewski, Wilhelm von Humboldt, Warszawa 1989, s. 274.

OGRody NAUK I SZTUK NR 2014 (4) 
Cassirer, który zradykalizował ujęcia I. Kanta, mówiąc, że nie możemy mówić o żadnej rzeczywistości samej w sobie. Wszystko poznajemy bowiem poprzez otaczające nas symbole, co pokazują następujące słowa filozofa: „,Człowiek nie potrafi się już bezpośrednio ustosunkować do rzeczywistości. Nie może jak gdyby stanąć z nią twarzą w twarz. W miarę jak symboliczna działalność człowieka robi postępy, rzeczywistość fizyczna zdaje się cofać. Zamiast zajmować się rzeczami samymi w sobie, człowiek w pewnym sensie ustawicznie sam z sobą rozmawia. Tak bardzo owiną się w formy językowe, w obrazy artystyczne, w mityczne symbole lub religijne obrządki, że nie potrafi już niczego zobaczyć ani poznać inaczej jak za pośrednictwem tego sztucznego środka" ${ }^{\prime \prime 10}$.

Z powyższych słów wynika, że dla E. Cassirera cała kultura jest symboliczna i mamy dostęp tylko do symboli, które stworzył człowiek. Z tej perspektywy również język jest pewną formą symboliczna, w której ujmujemy świat i dzięki której jesteśmy w stanie go poznawać.

Spojrzenie kantowskie na język wskazuje więc, że poznanie rzeczywistości jest uzależnione od podmiotu, który poznaje. Język jest tu jedną z głównych cech tego podmiotu, dzięki której świat jest dla niego poznawalny. Pogląd ten rozwinął także Leo Weisgerber, dla którego rzeczywistość może być dostępna człowiekowi tylko poprzez nazwy. Bolesław Andrzejewski, który przedstawił teorię L. Weisgerbera, pisze o tym w następujących słowach: „Język jest zatem nieodzownym czynnikiem w procesie kształtowania się myśli - warunkiem znajomości czegoś jest jego nazwanie (»znalezienie słowa jest jednoznaczne ze znalezieniem samej rzeczy«). Dzięki słowom wyprecyzowują się pojęcia, zaś odpowiadające im rzeczy stają się treścią naszej świadomości. Dzięki językowi przyroda zostaje uporządkowana i poznawczo dostępna, lepiej wyodrębniają się jej poszczególne części, możliwe staje się dokonywanie porównań i wartościowań” ${ }^{\prime 11}$.

Widać wyraźnie, że filozoficzny pogląd o pierwszorzędnym znaczeniu języka w ludzkim poznaniu, jest głęboko zakorzeniony w tradycji, która rozwinęła myśl Kanta. Treść twierdzeń W. von Humboldta, E. Cassirera i L. Weisgerbera jest zgodna co do tego, że ludzkie doświadczenie uzależnione jest od języka, który pełni funkcję porządkującą doznania zmysłowe. Z tej perspektywy uprawnione może być, przedstawiane tu twierdzenie, że można język postrzegaćjako pewnego rodzaju „pojemnik na doświadczenie”.

Pokazując tę kwestię na przykładzie, można odnieść się do wzrokowego doświadczenia określonego koloru. Gdy mówimy „niebieski”, wkładamy w to pojęcie wrażenia zmysłowe, ale to właśnie dzięki niemu jesteśmy w stanie w ogóle wyodrębnić je $\mathrm{w}$ doświadczeniu. Bez porządkującego pojęcia doświadczalibyśmy jedynie bezładnej plątaniny wrażeń. Pozwala nam ono włożyć te wrażenia w pewną kategorię. Dzięki temu potrafimy odróżniać kolor niebieski od czerwonego. Czy jednak możemy mieć dostęp do doznań drugiego człowieka, które określa on tym samym pojęciem? Z tez E. Cassirera i L. Weisgerbera, które pokrótce zostały tutaj przedstawione, można wnioskować, że poruszamy się jedynie w obrębie symboli, języka i nazw. Jednak powyższe pytanie sięga głębiej. Czy osobiste wrażenia związane z danym pojęciem są w ogóle możliwe do przekazania drugiej osobie? Być może w komunikacji bawimy się jedynie „pudełkami”, bez względu na to, jaką mają zawartość.

\section{LUDWIG WITTGENSTEIN I , ŻंUK W PUDEeKU"}

Kwestię możliwości przekazywania osobistych odczuć poprzezjęzyk podjął w swoich rozważaniach austriacki filozof Ludwig Wittgenstein. W pracy pt. Dociekania filozoficzne przedstawił on koncepcjęjęzyka w działaniu, opartą na założeniu, że znaczenie słów jest określone poprzez ich użycie. Przyrównuje on wyrażenia językowe do narzędzi, którymi posługujemy się w codziennych sytuacjach ${ }^{12}$. Wprowadza przy tym także termin „gra językowa” na określenie konkretnych użyć języka w zależności od kontekstu¹3. Takie ujęcie zakłada, że to właśnie język w działaniu ma większe znaczenie niż sama jego struktura.

Gdy zestawi się to z tym, co już do tej pory zostało napisane w tym artykule o języku z pozycji kantyzmu, można powiedzieć, że owszem, język porządkuje nasze doświadczenie, ale w codziennym życiu większego znaczenia nabiera jego użycie. Ludzie rozumieją język poprzez jego używanie. Stanowisko to wskazuje, że język jest sferą intersubiektywna, co do której musi istnieć powszechna zgoda użytkowników. „Gra językowa” bowiem musi być rozumiana przez jej uczestników. Gdy wszyscy "grają" według tych samych zasad - odgrywają tą samą „grę" - nie ma trudności z porozumiewaniem się oraz rozumieniem znaczenia wyrażeń.

10 E. Cassirer, Esej o czlowieku, Warszawa 1977, s. 80

11 B. Andrzejewski, Poznanie..., dz. cyt., s. 61

12 L. Wittgenstein, dz. cyt., s. 13-14.

13 Tamże, s. 20. 
Z powyższych powodów L. Wittgenstein występuje z koncepcja, która mówi, że osobiste doświadczenie nie odgrywa $\mathrm{w}$ „grach językowych" żadnej roli. Należy przypomnieć, że chodzi tu m. in. o doświadczenia zmysłowe, jak np. odczuwanie bólu. L. Wittgenstein twierdzi, że nie możemy poprzez język przekazać swoich przeżyć drugiemu człowiekowi, lecz fakt ten nie ma żadnego związku ze skutecznością używania języka. Po prostu osobiste przeżycia drugiej osoby są z tego punktu widzenia niedostępne, a co za tym idzie, są nieistotne. Będzie to widać wyraźnie w słowach filozofa przytoczonych poniżej $j^{14}$.

L. Wittgenstein posługuje się tu eksperymentem myślowym, który ma uwidocznić jego twierdzenia w tym zakresie. Właśnie tu pojawia się odniesienie do „pudełka”, które jest traktowane przez niego jak wyrażenie językowe mające określać jakiś stan psychiczny, czy też doznanie użytkownika. W szerszym kontekście eksperyment ten wskazuje także na wspomnianą intersubiektywność języka. Odnośnie doznań, takich jak np. ból, ma pokazywać, że język nie potrafi ich przekazać. Wittgenstein przedstawia swoją koncepcję w następujący sposób: „Przypuśćmy, że każdy miałby pudełko zawierające coś, co nazywamy »żukiem «. Nikt nigdy nie może zajrzeć do cudzego pudełka; i każdy mówi, że tylko z widoku swego żuka wie, co to jest żuk. - Mogłoby się zdarzyć, że każdy miałby w swym pudełku co innego. Można by sobie nawet wyobrazić, że rzecz ta stale by się zmieniała. - Gdyby jednak mimo to słowo »żuk« miało dla tych ludzi jakieś zastosowanie, wtedy byłoby ono zastosowaniem nazwy pewnej rzeczy. Rzecz w pudełku nie należy w ogóle do gry językowej; nawet nie jako coś, gdyż pudełko mogłoby być też puste. - Nie, przez ową rzecz w pudełku można »upraszczać«, ona się znosi, czymkolwiek by była"15.

Autor wyraźnie stwierdza, że posługiwanie się wyrażeniami językowymi pozwala jedynie na dostęp do własnych przeżyć, które te wyrażenia opisują. Zawartość „pudełka” drugiej osoby zawsze zostaje przed nami ukryta. Używamy jedynie określonej nazwy, której użycie ma znaczenie, nie zaś to, do czego się odnosi. Perspektywa ta pokazuje, że z punktu widzenia porozumiewania się z innymi ludźmi, to, co zawiera się $\mathrm{w}$,|językowych pudełkach", nie ma znaczenia dla prawidłowego przebiegu rozmowy.

Czy w takim razie możliwe jest, że pewne osoby posługują się, w niektórych przypadkach, „pustymi pudełkami”? Być może zawartość „pudełek” poszczególnych ludzi różni się od siebie. Co mogłoby oznaczać posługiwanie się „pustymi pudełkami"? Czy taka sytuacja w ogóle może mieć miejsce? Jak do tego ma się użycie języka? Kwestie te może rozświetlić jeszcze jeden eksperyment myślowy.

\section{JoHN SEARLE I "CHIŃSKI POKÓJ"}

Eksperyment $\mathrm{z}$ „,hińskim pokojem” zaprezentowany przez Johna Searléa został skonstruowany w ramach refleksji nad ludzkim umysłem. Głównym pytaniem filozoficznym, na które próbował odpowiedzieć J. Searle było to, czy ludzki umysł działa jak program komputerowy, co było zgodne z wieloma koncepcjami podejmującymi to zagadnienie. J. Searle, aby uwidocznić błąd takiego rozumowania próbował wykazać, że w umyśle muszą znajdować się jakości, które wykraczają poza zwykłe przetwarzanie danych na wzór komputera. W odniesieniu do języka, miało to pokazać głównie, że opiera się on także na semantyce - odniesieniu do świata rzeczywistego, a nie tylko na syntaktyce - relacjach między znakami ${ }^{16}$. Efektem tych rozmyślań stał się „",hiński pokójj"17.

Treść eksperymentu opiera się na sytuacji, $w$ której osoba nieznająca języka chińskiego posiada dostęp do całego słownictwa oraz wszystkich reguł gramatycznych związanych z nim. Dzięki tej wiedzy jest w stanie odpowiadać na dowolne pytania w języku chińskim, bez rozumienia tego języka. Osoba ta jest zamknięta w pokoju, do którego przez mały otwór wsuwane są pytania napisane po chińsku. Korzystając ze zbioru znaków oraz zasad ich łączenia ze soba, potrafi ona odpowiedzieć zupełnie poprawnie na każde pytanie. Czy jednak osoba taka rozumie chiński poprzez sam fakt skutecznego posługiwania się znakami tego języka? Odpowiedź J. Searle'a jest negatywna, co ma dowodzić, że umysł, to coś więcej, niż tylko komputer ${ }^{18}$.

Jednakże to, co jest najważniejsze z punktu widzenia tego artykułu, kryje się w założeniu, że nie ma żadnych przeszkód, żeby poprawnie posługiwać się wyrażeniami danego języka bez znajomości tego, do czego się one odnoszą. Tak więc używanie „pustych pudełek” można uznać za możliwe, tak samo jak używanie pustych chińskich znaków. Prowadzi

\footnotetext{
14 Tamże, s. 144.

15 Tamże.

16 J. Searle, dz. cyt., s. 28.

17 Tamże, s. 28-30.
}

18 Tamże. 
to do stwierdzenia, że można postrzegaćjęzyk wręcz przedmiotowo, traktując go niemal jak każdąinną część poznawanej rzeczywistości. Mówiąc inaczej, takie „puste pudełko" może mieć poznawczo taki sam status jak np. doznania zmysłowe. Wynika to z założenia, że zbiór kresek układających się w chiński znak nie różni się w doświadczeniu zmysłowym od przypadkowego zbioru kresek. Różnica w takim wypadku, można by rzec, jest tylko ilościowa, nie odnosi się do niczego poza samymi danymi zmysłowymi jakie się przy tym odbiera.

Trzeba też zaznaczyć, że eksperyment J. Searléa może mieć wielkie znaczenie w odniesieniu do jednostki, która posługuje się językiem. Wskazuje on bowiem, że zawsze w mniejszym lub większym stopniu, powinna zachodzić korelacja między wyrażeniami danego języka, a tym do czego się one odnoszą albo co w sobie zawierają. Dowód przedstawiony przez filozofa pokazuje, że człowiek posiada całą gamę wewnętrznych przeżyć, które są czymś więcej, niż tylko zdolnościami obliczeniowymi, nakierowanymi na funkcjonowanie w rzeczywistości. Niesie to za sobą stwierdzenie, że nie można mówić, że osoby, które posługują się „pudełkami” nie mają przeżyć, lecz z punktu widzenia L. Wittgensteina po prostu nie dotrze się do tych przeżyć poprzez język.

Rozważania tego typu nie miałby jednak żadnego znaczenia, gdyby nie można było odnieść ich do rzeczywistości. Jak się okaże, zjawisko autyzmu może być zinterpretowane dzięki takiemu podejściu. Zanim jednak ta kwestia zostanie podjęta, trzeba podsumować to, co zostało już powiedziane. Zaczynając od początku: (1) język może być postrzegany jako porządkujący „pojemnik” na szeroko pojęte doświadczenie, ale (2) w porozumiewaniu się zawartość tego „pojemnika” nie odgrywa większej roli, o ile język jest używany zgodnie z zasadami określonej „gry", co prowadzi do stwierdzenia, że (3) można posługiwać się jedynie pustymi „pojemnikami” oraz (4) ludzki umyst jest czymś więcej niż komputer.

Odniesienie tych stwierdzeń do autyzmu może zwrócić uwagę na kilka bardzo istotnych kwestii związanych z posługiwaniem się językiem przez osoby z autyzmem.

\section{AUTYZM, „PUDEEKA" I FILOZOFIA JĘZYKA}

Celem tego tekstu nie jest wyjaśnianie w żaden sposób istoty zjawiska autyzmu. Jest to zagadnienie równie głębokie, jak niejeden problem filozoficzny, który zajmował myślicieli przez wiele minionych epok. To, co zostanie tu przedstawione, to jedynie nałożenie powyższej perspektywy filozofii języka na aspekty związane z komunikacją osób z autyzmem.

Na początek tej części należy zatem wspomnieć, że problemy w komunikacji są jedną z głównych cech towarzyszących autyzmowi. To właśnie utrudnienia w nawiązywaniu kontaktów z innymi ludźmi sprawiaja, że owo zjawisko jest nadal tak niezrozumiałe. Trzeba też wspomnieć, że autyzm nie jest zaburzeniem jednorodnym. Istnieje wiele poziomów i typów, w których może występować. Alicja Rakowska podsumowuje aspekty autyzmu, co do których zgadza się większość badaczy: „Różne sposoby klasyfikowania autyzmu wczesnodziecięcego dowodza, że poglądy na istotę tego zaburzenia są rozbieżne. Jednak z reguły badacze są zgodni, że w autyzmie występują trzy najważniejsze objawy:

- nieprawidłowe więzi społeczne i rozwój społeczny,

- niezdolność nawiązania prawidłowej komunikacji,

- $\quad$ zainteresowania i czynności dziecka są ograniczone i powtarzające się, a nie elastyczne i twórcze ${ }^{\prime \prime 19}$.

Dwa pierwsze z powyżej wymienionych punktów odnoszą się bezpośrednio do zagadnienia, które jest tu poruszane, bowiem komunikacja oraz budowanie relacji społecznych nie dają się w zasadzie oddzielić od siebie. Istnieje więc zgoda, co do tego, że te aspekty w przypadku autyzmu ulegają pewnym zaburzeniom. W tym miejscu można zapytać za Danutą i Andrzejem Wolskimi: „Rodzi się pytanie: Czy dzieci autystyczne nie chcą komunikować się (brakuje im motywacji) czy też nie wiedza, do czego tak naprawdę służy komunikacja, co można przy jej pomocy osiagną́ć w kontaktach z innymi osobami?"20.

Można by to pytanie przeformułować, odnosząc się do metafory „pudełka” L. Wittgensteina. Czy osoby z autyzmem nie chcą używać „pudełek", czy też nie wiedzą do czego one stużą? L. Wittgenstein przedstawia bowiem perspektywę w której to używanie „pudełka” w kontekście społecznym jest najważniejsze, co z powodzeniem można odnieść do problemu poprawnej komunikacji i zaburzenia relacji społecznych u osób z autyzmem. Cały problem z tej perspektywy koncentrowałby się na poprawnym uczestniczeniu w "grze językowej”, co wiąże się z odpowiednim użyciem „pudełek językowych”. Jest tu jeszcze jeden aspekt, czy właściwe używanie „pudełka” wiąże się również z dopasowaniem odpowiedniej zawartości? Oto co na ten temat piszą D. i A. Wolscy: „Nawet dzieci, które stosunkowo dobrze opanowały funkcję mowy, mają problemy z prowadzeniem konwersacji, a zakres poruszanych przez nie tematów jest znacznie

19 A. Rakowska, Język-komunikacja-niepetnosprawność. Wybrane zagadnienia, Kraków 2003, s. 143-144.

20 D. i A. Wolscy, Rozwijanie kompetencji komunikacyjnej u dzieci z autyzmem, [w:] J. Baran, A. Mikruta (red.), Umiejętności komunikacyjne osób z niepetnosprawnością. Teoria, diagnoza, wspomaganie, Kraków 2007, s. 178. 
ograniczony. Ich możliwości rozumienia zjawisk są ograniczone, a to, co do nich dociera, pojmują bardzo dosłownie, nie będąc w stanie zanalizować pojęć abstrakcyjnych. Większość nie potrafi mówić o uczuciach lub myślach, nie są w stanie za pomocąjęzyka dawać upustu swoim emocjom"21.

Osoby z autyzmem wykazują nie tylko problemy z dopasowywaniem swoich wypowiedzi do kontekstu konwersacji, ale także nie potrafią ujmować swoich emocji i przeżyć w języku. Odnosząc się do metafory „pudełek”, można powiedzieć, że nie są w stanie, bądź nie chca, „wkładać zabawek do pudełek”. Zabawki, jak było powiedziane we wstępie, mają tu symbolizować szeroko pojęte doświadczenie, w tym emocje. Problem z wyrażaniem emocji przez osoby z autyzmem, z punktu widzenia perspektywy tu przedstawionej, polegałby na braku korelacji pomiędzy zawartością a pojemnikiem. Warto przy tym zauważyć, że brak możliwości wyrażania się poprzez język, nie oznacza wcale braku życia wewnętrznego. Jak pisze Oliver Sacks odnosząc się do przełomowego charakteru książki Myślenie obrazami Temple Grandin: „ (...) w medycynie od ponad czterdziestu lat panował dogmat, że ludzie autystyczni nie mają »wnętrza«, to jest życia wewnętrznego, a jeśli nawet coś takiego istnieje, to nie da się do niego dotrzeć ani go uzewnętrznić $(. . .)^{\prime \prime 22}$.

Relacja T. Grandin okazała się jednak przełomowa, ponieważ pokazała, że taki pogląd jest bezpodstawny. Można jednak zadać pytanie, skąd wzięło się przekonanie o braku życia wewnętrznego u osób z autyzmem? W powyższym cytacie ważne jest wskazanie, że podejrzewano, iż nawet jeśli takie życie istnieje, to nie można do niego dotrzeć. Dlaczego? Z punktu widzenia, który jest prezentowany w tym artykule, działo się tak właśnie dlatego, że nie było możliwe poprawne porozumiewanie się z takimi osobami. Nie "grały one w tą samą grę językową", co uniemożliwiało im uczestniczenie w życiu społecznym. Dlaczego książka T. Grandin wniosła tak wiele, że aż zmieniła postrzeganie osób z autyzmem? Gdyż przekazała relację ze świata autyzmu w „grze językowej”" zrozumiałej dla każdego. Mimo, że z punktu widzenie L. Wittgensteina i tak nie można mieć bezpośredniego wglądu w cudze przeżycia, to język jest nieodzowny z punktu widzenia funkcjonowania w społeczeństwie. Granie w tą samą „grę językową" zapewnia zrozumienie. Tezy L. Wittgensteina, co do niemożliwości poznania osobistych przeżyć drugiej osoby przez język, wcale nie stoją tutaj w sprzeczności z twierdzeniem o głębszym zrozumieniu autyzmu poprzez dopasowanie "gry językowej”. Jeśli odniesie się to znów do przykładu ksiązi T. Grandin jako „gry” zrozumiałej dla większości, potwierdzi się, że dopiero kiedy autyzm „zagrał z nami w tą samą grę" stał się zrozumiały. Wiąże się to też niewątpliwie z tym, że taka "gra", używająca ogólnie przyjętych wyrażeń, pozwalała na odniesienie ich do własnych przeżyć. Czyli osoby, które nie posiadają autyzmu zrozumiały to zjawisko w odniesieniu do swojego doświadczenia.

Kwestię przeżyć wewnętrznych osób z autyzmem można też odnieść do stanowiska J. Searle'a. Każdy, kto posługuje się wyrażeniami danego języka, musi mieć mentalne odniesienia z nimi związane, w przeciwnym razie zachowuje sięjak program komputerowy. Z tej jednostkowej perspektywy można powiedzieć, że osoby z autyzmem również muszą posiadać przeżycia wewnętrzne. Problem polega właśnie na braku korelacji między wyrażeniami i przeżyciami. Możliwość operowania na samych „pustych pudełkach" może obrazować właśnie sytuację, kiedy nie ma korelacji między wyrażeniem a przeżyciem; wyrażenia, jak zostało pokazane powyżej, mogą być takimi samymi przeżyciami jak inne. Problem polega na kojarzeniu ich ze sobą w odpowiedni sposób.

Jak zatem język funkcjonuje z perspektywy osoby z autyzmem? T. Grandin określa swój typ myślenia jako „myślenie obrazami”: „Myślę obrazami. Słowa są dla mnie jakby językiem wyuczonym. Tak mowę, jak i pismo przekładam sobie na kolorowe obrazy z podkładem dźwiękowym, które wyświetlają się w mojej głowie jak zapis z taśmy wideo. Gdy ktoś się do mnie zwraca, jego słowa zostają automatycznie przetłumaczone na obrazy"23. Autorka podkreśla jednak, że nie jest to regułą dla wszystkich typów autyzmu. Ważne jest zwrócenie uwagi na odnoszenie się do obrazowego pojmowania świata. Widać, że język w takim przypadku może być czymś niezrozumiałym dla osoby myślącej poprzez konkretne, wizualne odniesienia. T. Grandin pisze także: „Gdy ja pracuję nad stworzeniem czegoś nowego, nie posługuję się językiem. Są ludzie, dla których pojęcia mają postać bardzo realistycznych i szczegółowych obrazów, ale u większości jest to połączenie słów z niewyraźnymi, raczej mglistymi wizjami. Wiele osób na przykład, czytając lub słysząc wyrażenie „wieża kościelna”, wyobraża sobie typowy kościół w ogólnym zarysie, nie zaś szczegółową konstrukcję określonej wieży lub kościoła. Ich szlak myślowy biegnie od pojęcia do konkretnych przykładów. Często zdarzało mi się odczuwać silną irytację, gdy ktoś myślący werbalnie nie mógł zrozumieć czegoś, co starałam się mu przekazać, ponieważ nie był w stanie zobaczyć obrazu, który dla mnie był czymś oczywistym"24.

21 P. Randall., J. Parker, Autyzm. Jak pomóc rodzinie, Gdańsk 2001, [cyt. za:] D. i A. Wolscy, Rozwijanie..., dz. cyt., s. 180.

22 0. Sacks, Przedmowa, [w:] T. Grandin, Myślenie obrazami oraz inne relacje z mojego życia z autyzmem, Warszawa 2006, s. 11.

23 T. Grandin, Myślenie..., dz. cyt., s. 19.

24 Tamże, s27.

OGRODY NAUK I SZTUK NR 2014 (4) 
Jeden z problemów T. Grandin w porozumiewaniu się z innymi polegał zatem na braku wzajemnego zrozumienia, wynikającym z różnych typów myślenia. Autorka sugeruje, że myślenie zapośredniczone poprzez język jest czymś innym niż myślenie obrazami. Pośrednio wskazuje także, że to właśnie język wpływa na kształtowanie myśli u osób, które nie są autystyczne. Natomiast podstawą dla T. Grandin były obrazy, które musiała się nauczyć kojarzyć z określonym pojęciem. Dla osób myślących językowo pojęcie ma pierwszeństwo przed doświadczeniem. Odnosząc to do perspektywy kantowskiej, forma językowa pozwala nam na ujmowanie rzeczywistości. Natomiast osoby myślące obrazami muszą nauczyć się wiązać swoje myśli z konkretnymi pojęciami, doświadczenie z językiem. T. Grandin pisze dalej: „Moje myśli, w przeciwieństwie do myśli wielu innych osób, biegną od realistycznych jak na filmie, bardzo konkretnych obrazów do uogólnień i pojęć. Na przykład pojęcie psa jest w moim umyśle nierozerwalnie związane z każdym psem, jakiego w życiu spotkałam"25.

Obrazy psów muszą zostać powiązane z kategorią "psy”, by móc skutecznie porozumiewać się tym wyrażeniem w kontaktach z innymi ludźmi. W przypadku autyzmu nie zachodzi naturalna korelacja między „pudełkami” a zawartością. Widać wyraźnie, że język dla osób z autyzmem musi przedstawiać się inaczej niż dla innych. Wygląda to tak jakby myślenie obrazami było innym rodzajem języka niż ten, który jest używany powszechnie. Dlatego porozumiewanie się z osobami z autyzmem może czasem przypominać pracę translatorską: „Wielu ludzi symbole, którymi posługują się osoby autystyczne, wprawiają w osłupienie, ale dla nich może to byćjedyna dostępna rzeczywistość lub sposób na zrozumienie świata. Na przykład »frytki« mogą oznaczać radość, jeśli jedzenie frytek sprawia dziecku wielką przyjemnośćn ${ }^{\prime \prime 2}$.

Ten oraz wiele innych przykładów przytaczanych przez T. Grandin wskazuja, że trzeba uczyć dzieci z autyzmem odpowiednich "gier językowych", bądź nauczyć się „gier" używanych przez takie dzieci. Wyrażenie „frytki" może być dla nich skorelowane z radościa. Jeśli będzie można się nauczyć użycia tego wyrażenia, to będzie ono zrozumiałe. Widać więc, że w relacjach społecznych możemy operować jedynie na "pudełkach”, nie zaś na zawartościach, choć ta ostatnia może mieć z punktu widzenia jednostki fundamentalne znaczenie. Słowo „frytki” może mieć inną zawartość dla różnych osób, odniesienie do przedmiotu, który postrzegamy zmysłowo, bądź do uczucia radości. Nie da się oczywiście odczuć radości osoby z autyzmem tylko na podstawie języka, jednak jeśli zrozumiemy użycie danego słowa, możemy je skutecznie odnieść do własnej radości, co znacznie pomaga w porozumiewaniu się i wzajemnym zrozumieniu.

Być może wyrażenia językowe dla osób z autyzmem są takim samym materiałem zmysłowym jak reszta otaczającego ich świata. Słowa nie są bezpośrednio łączone z przedmiotami, gdyż należą do tej samej kategorii co przedmioty. T. Grandin wielokrotnie wspomina o ciagach skojarzeń, które prowadzą do danego wyrażenia, jak było to z psem i wieżą kościelną. Można powiedzieć, że w pewien sposób musiała się ona nauczyć kojarzyć obrazy przedmiotów z obrazami słów. Jest to jedynie teza, która wymagałaby głębszych badań, wykraczających poza ramy tego artykułu.

\section{ZAKońCZenIE}

Co mówi autyzm? Gdy zestawi się przywołaną tu perspektywę filozofii języka z kwestią autyzmu, można powiedzieć, że autyzm mówi ,językowymi pudełkami”. Tylko wtedy może być zrozumiany. I choć nie oznacza to dokładnego poznania przeżyć osób z autyzmem, sprawia, że jesteśmy w stanie się z nimi porozumieć. Żeby komunikacja przebiegała sprawnie musi zaistnieć pewna korelacja pomiędzy „pudełkami”, a zawartością. Niestety ta zawartość może być w wielu przypadkach różna, wtedy konieczne jest odkrycie znaczenia wyrażenia poprzez „grę językową". Żeby bowiem autyzm był zrozumiały dla innych ludzi musi grać w tę samą „„grę".

Gdy osoby z autyzmem tworzą charakterystyczne tylko dla siebie sposoby wyrażania się, posługiwania językiem, co wskazuje m. in. klasyfikacja DSM-IV"27, nie są one w stanie porozumieć się z innymi. Jest to również zgodne z poglądem L. Wittgensteina, który krytykował koncepcję jezzyka prywatnego ${ }^{28}$. To jedynie intersubiektywny charakter języka pozwala na prawidłowe porozumiewanie się.

Język jest zatem „pudełkiem” na ludzkie przeżycia. Może być ono puste, można się uczyć języka tylko na zasadzie operowania takimi „pustymi pudełkami”. Nie oznacza to jednak, że osoby, które z nich nie korzystaja, nie mają przeżyć wewnętrznych. Autyzm pokazuje, że istnieją sytuacje, w których faktycznie nie zachodzi korelacja pomiędzy przeżyciami a ,językowymi pudełkami". Jawią się osobom z autyzmem jako coś nieprzydatnego w procesie wyrażania swoich emocji. Dlatego wiele wysiłków mających na celu usprawnienie komunikacji z osobami z autyzmem opiera się na stosowaniu metod

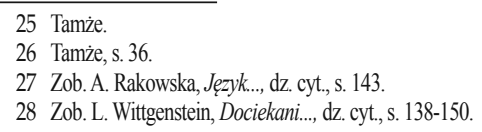


alternatywnych jak np. system piktogramów ${ }^{29}$. Można stwierdzić, że w takich wypadkach po prostu poszukuje się odpowiednich „pudełek”, dzięki którym będzie możliwe poprawne porozumiewanie się. Tak więc można w tej sytuacji operować jedynie na "pojemnikach".

Z punktu widzenia samej refleksji nad językiem, trzeba przyznać, że przykład autyzmu wskazuje, że język nie funkcjonuje zawsze w taki sam sposób. Nie spełnia on tej samej roli dla każdego człowieka. Osoby z autyzmem uczą się języka na zasadzie skojarzeń. Myślenie obrazami może pokazywać, żejęzyk również jest rodzajem obrazów. Wtedy cały problem polegałby na zestawieniu ze sobą odpowiednich obrazów. Język sam w sobie mógłby być postrzegany jako przedmiot doświadczenia równy np. jakościom zmysłowym. Wtedy można twierdzić, że jest on równie przydatnym źródłem informacji jak wszystkie dane, które są dostarczane człowiekowi poprzez zmysły. Należy tylko dotrzeć do tej informacji.

Odnosząc całość przedstawionych tu wątków do eksperymentu myślowego z początku artykułu, można powiedzieć, że niektóre dzieci nie wiedzą jak posługiwać się „pudełkami”, i co należy w nie wkładać. Dlatego „pudełko” z napisem "samochód”, czy „frytki" może w takich przypadkach wielokrotnie zawierać coś innego albo być zupełnie puste. Najważniejsze wnioski jakie się tu nasuwają w odniesieniu do autyzmu to: (1) język funkcjonuje w oparciu o korelację szeroko pojętego doświadczenia z formą danego języka - „zabawki” i „pudełka”, (2) z punktu widzenia porozumiewania się z innymi najważniejsze jest użycie języka, czyli same "pudełko”, ale (3) aspekt łączenia zawartości z „pudełkiem” może mieć duże znaczenie z punktu widzenia jednostki posługującej się językiem, gdyż wiąże się to z umiejętnością wyrażania swoich stanów wewnętrznych, mimo, że inni będąje rozumieć jedynie w odniesieniu do własnych stanów, (4) dlatego ważne jest dopasowywanie się do gier językowych, gdyż przez nie możemy się lepiej rozumieć na poziomie społecznym, (5) autyzm $\mathrm{z}$ tego punktu widzenia przedstawia się jako sposób myślenia, który nie uznaje ważności „pudełek” w budowaniu relacji społecznych, dlatego osoby z autyzmem muszą uczyć się wkładania zabawek do „pudełek”, by w ogóle uznać ich przydatność, co z punktu widzenia filozofii języka pokazuje, że (6) język nie odgrywa takiej samej roli we wszystkich przypadkach i nie funkcjonuje w jeden określony sposób. Dodatkowo można zwrócić uwagę na możliwość postrzegania języka jako danej zmysłowej, co może być widoczne np. w przypadku myślenia obrazami.

Nauki, takie jak filozofia języka, mogą zatem czerpać wiele z rzeczywistych przypadków, które często wskazuja że nie wszystko da się wyjaśnić jedną teorią. Język jest sfera, która nadal zajmuje naukowców różnych dziedzin, od filozofów, przez filologów, po lingwistów. Poznawanie języka łączy się z głębszym rozumieniem człowieka. Przykłady takie jak autyzm pokazuja, że trzeba pogodzić się z wielką różnorodnością sposobów, w jaki poznaje on świat i jak w nim funkcjonuje.

\section{Bibliografia}

[1] Andrzejewski B., Poznanie i komunikacia, Koszalin 2010.

[2] Andrzejewski B., Wilhelm von Humboldt, Warszawa 1989.

[3] Baran J., Mikruta A. (red.), Umiejẹtnósci komunikacyjne osób z niepethosprawnościa. Teoria, diagnoza, wsppomaganie, Kraków 2007.

[4] Cassirer E., Esej o czlowieku, Warszawa 1977.

[5] Grandin T., Mýsenie obrazami oraz inne relacje z mojego życia z autyzmem, Warszawa 2006.

[6] Kant I., Krytyka czystego rozumu, T. I, Warszawa 1957.

[7] Rakowska A., Jezyk-komunikacia - niepehnosprawność. Wybrane zagadnienia, Kraków 2003.

[8] Searle J., Umyst, mózg i nauka, Warszawa 1995.

[9] Tatarkiewicz W., Historia filozofii, T. II, Warszawa 2007.

[10] Wittgenstein L., Dociekania filozoficzne, Warszawa 2000.

29 Zob. A. Rakowska, Język..., dz. cyt., s. 151-153.

OGRODY NAUK I SZTUK NR 2014 (4) 